\title{
In situ ruminal degradation characteristics of dry matter and crude protein from dried corn, high-protein corn, and wheat distillers grains
}

\author{
Y. H. Lee, F. Ahmadi, D. Y. Choi and W. S. Kwak (1)
}

\begin{abstract}
Background: The continuing growth of the ethanol industry has generated large amounts of various distillers grains co-products. These are characterized by a wide variation in chemical composition and ruminal degradability. Therefore, their precise formulation in the ruminant diet requires the systematic evaluation of their degradation profiles in the rumen.

Methods: Three distillers grains plus soluble co-products (DDGS) namely, corn DDGS, high-protein corn DDGS (HP-DDGS), and wheat DDGS, were subjected to an in situ trial to determine the degradation kinetics of the dry matter (DM) and crude protein (CP). Soybean meal (SBM), a feed with highly degradable protein in the rumen, was included as the fourth feed. The four feeds were incubated in duplicate at each time point in the rumen of three ruminally cannulated Hanwoo cattle for 1, 2, 4, 6, 8, 12, 24, and 48 h.

Results: Wheat DDGS had the highest filterable and soluble A fraction of its DM (37.2\%), but the lowest degradable B (49.5\%; $P<0.001)$ and an undegradable $C$ fraction $(13.3 \% ; P<0.001)$. The filterable and soluble $A$ fraction of CP was greatest with wheat DDGS, intermediate with corn DDGS, and lowest with HP-DDGS and SBM; however, the undegradable $C$ fraction of CP was the greatest with HP-DDGS (41.2\%), intermediate with corn $\operatorname{DDGS}(2.7 \%)$, and lowest with wheat DDGS and SMB (average $4.3 \%$ ). The degradation rate of degradable B fraction $\left(\% \mathrm{~h}^{-1}\right)$ was ranked from highest to lowest as follows for 1) DM: SBM (13.3), wheat DDGS (9.1), and corn DDGS and HP-DDGS (average 5.2); 2) CP: SBM (17.6), wheat DDGS (11.6), and corn DDGS and HP-DDGS (average 4.4). The in situ effective degradability of $C P$, assuming a passage rate of $0.06 \mathrm{~h}^{-1}$, was the highest $(P<0.001)$ for SBM (73.9 \%) and wheat DDGS (71.2\%), intermediate for corn DDGS (42.5\%), and the lowest for HP-DDGS (28.6 \%), which suggests that corn DDGS and HP-DDGS are a good source of undegraded intake protein for ruminants.

Conclusions: This study provided a comparative estimate of ruminal DM and CP degradation characteristics for three DDGS co-products and SBM, which might be useful for their inclusion in the diet according to the ruminally undegraded to degraded intake protein ratio.
\end{abstract}

Keywords: Crude protein, Dried distillers grains with solubles, Undegraded intake protein, In situ rumen degradation

\footnotetext{
* Correspondence: wsk@kku.ac.kr

Division of Food Biosciences, College of Medical Life Sciences, Konkuk

University, Chung-Ju, Chung-Buk 380-701, Korea
} 


\section{Background}

Dried distillers grains with solubles (DDGS), generated after the fermentation and distillation in a grain-based ethanol production [1], are an excellent and economical source of protein and energy for livestock, especially dairy and beef cattle. Although similar to the original grain, DDGS is usually richer in protein, fat, and fiber concentrations [2, 3]. Relative to SBM, DDGS coproducts are generally recognized to have a proportionately higher ruminally undegraded intake protein (UIP) content. This is because most of the readily degradable protein in the grain is degraded during the fermentation process [3]. For example, the National Research Council [4] estimates that corn DDGS contains approximately $30 \%$ crude protein, where UIP constitutes about $73 \%$ of crude protein (CP).

The rapidly expanding ethanol industry will contribute significantly to an increased supply of DDGS at a competitive cost $[5,6]$. However, considerable variation in the processing technologies among the dry-milling industries and the raw grains entering the plants, substantially alter the chemical composition and ruminal degradation properties of DDGS co-products. This necessitates a more accurate estimate of ruminal degradation kinetics of dry matter (DM) and CP fractions. Reliably determining the dynamic models of carbohydrate and protein digestion is key to gaining the maximum economic benefit from these co-products [7-9]. Therefore, to precisely formulate diets to meet, but not exceed, the protein requirement of the ruminant, there is an urgent need to more specifically characterize the protein (especially the UIP fraction) degradation kinetics of these co-products in the rumen $[6,10]$. This will subsequently mitigate excessive $\mathrm{N}$ loss into the environment, and have economic benefits while supporting optimal animal performance [11]. Therefore, this study aims to compare in situ ruminal fractions, ruminal disappearance rate, and effective degradability (ED) of DM and $\mathrm{CP}$ in corn, high-protein corn, and wheat DDGS with those of SBM.

\section{Methods}

\section{Sample preparation and chemical composition}

In an attempt to collect representative samples, three different batches of each sample, on three different days throughout the months of July and August 2014, were obtained through Egreen Co. (Egreen Co. Ltd., Icheon, South Korea). Samples of HP-DDGS and corn DDGS were originated from ethanol plants in Valero's ethanol plant in Jefferson, Wisconsin (USA) and wheat DDGS was originated from bioethanol plants located in western Canada. However, the detailed information of the DDGS co-products, including the processing conditions at the ethanol production plant, were not available for this experiment owing to the difficulty in tracing detailed international information in a practical manner.

Subsamples of feeds were mixed thoroughly and hammer-milled (Cemotec, Tecator, Sweden) to pass through a 1-mm sieve, prior to being analyzed [12] for contents of DM, CP, ether extract (EE), and crude ash. Neutral detergent fiber (NDF; with heat-stable amylase and without sodium sulfite) and acid detergent fiber (ADF) content were determined using the procedure of Van Soest et al. [13]. True protein was quantified with the precipitation of the $\mathrm{N}$ fractions in a $5 \%$ trichloroacetic acid solution. Difference between CP $(\mathrm{N} \times 6.25)$ and true protein was defined as nonprotein N (NPN) [14].

\section{In situ ruminal incubations}

All procedures involving animals were reviewed and approved by the Konkuk University Institutional Animal Care and Use Committee. Details for the measurements of in situ degradability were described earlier [15]. Briefly, each sample was hammer-milled and passed through a 2-mm sieve, pooled to form one homogeneous preparation, and then randomly divided into 12 sub-samples for the in situ incubations (6 for each run). Each 5-g feed sample (DM basis; particles in a size range of $63 \mu \mathrm{m}$ to $2 \mathrm{~mm})$ was placed in a Dacron bag $(10 \times$ $20 \mathrm{~cm}, 53 \pm 10 \mu \mathrm{m}$ pore size; R1020, Ankom Technology, Macedon, NY, USA), and then suspended in the rumen of three cannulated Hanwoo cattle (body weight $=440.3 \pm$ $29.17 \mathrm{~kg}$, mean $\pm \mathrm{SD}$ ), which were fed a total mixed ration containing sudangrass silage $(7.4 \% \mathrm{CP}, 60 \% \mathrm{NDF}$ and $43 \% \mathrm{ADF}$ ) and a concentrate mix of $14.3 \% \mathrm{CP}$ and $6.3 \%$ CF. The proportion of the sample weight (DM basis) to the Dacron bag surface area was $40 \mathrm{mg} /$ $\mathrm{cm}^{2}$. For simultaneous removal of all bags from the rumen, Dacron bags were incubated at 1, 2, 4, 6, 8, 12, 24 , and $48 \mathrm{~h}$ and placed in the rumen in reverse order of incubation time. After the incubation was completed, bags were washed under running tap water until clear water emerged from the bag, and then dried at $55{ }^{\circ} \mathrm{C}$ for $48 \mathrm{~h}$. Zero hour bags were not placed in the rumen but were subjected to the same rinsing procedures as described for rumen-incubated samples.

In situ degradation curves of DM and CP were fitted to the exponential model described by Ørskov and McDonald [16]. The ruminal ED of DM and CP, assuming two fractional passage rates $\left(K_{\mathrm{p}} \mathrm{B}\right)$ from the rumen of 0.06 and $0.025 \mathrm{~h}^{-1}$, was calculated according to the following equation [16]:

$$
\mathrm{ED}=\mathrm{A}+\mathrm{B}\left[K_{\mathrm{d}} \mathrm{B} /\left(K_{\mathrm{d}} \mathrm{B}+K_{\mathrm{p}} \mathrm{B}\right)\right]
$$

where $\mathrm{A}=53-\mu \mathrm{m}$ filterable and soluble fraction, which was washed out without rumen incubation, $\mathrm{B}=$ potentially 
degradable fraction, which was degraded exponentially, $K_{\mathrm{d}} \mathrm{B}=$ the degradation rate of degradable $\mathrm{B}$ fraction, and $K_{\mathrm{p}} \mathrm{B}=$ the passage rate of degradable $\mathrm{B}$ fraction. The ED of $\mathrm{CP}$ was considered to be DIP, and estimated UIP was calculated as $[100-\%$ DIP] [17]. The undegradable fraction (C) was estimated as $[1-(\mathrm{A}+\mathrm{B})]$.

\section{Statistical analysis}

In situ data for each feed were a mean of 12 observations, which were obtained over the course of two consecutive runs at two different days. The experimental design was 2 consecutive incubations $\times 4$ feeds $\times 3$ animal replicates $\times 2$ sample replicates, giving a total of 48 observations. The data were analyzed using the PROC MIXED of SAS (version 9.1; SAS Inst., Inc., Cary, NC, USA), where feed sources were considered fixed effects and incubation run in the rumen was assumed to be random effect. The animal data were averaged prior to statistical analysis. The model used for the analysis was: $\mathrm{Y}_{i j}=\mu+\mathrm{F}_{i}+\mathrm{R}_{j}+\mathrm{e}_{i j}$, where, $\mathrm{Y}_{i j}=$ the observation of the dependent variable $i j ; \mu=$ the overall mean of $\mathrm{Y}_{i} \mathrm{~F}_{i}=$ the effect of feed $(i=4), \mathrm{R}=$ the effect of incubation run as replications $(j=2)$, and $e i j=$ the random error associated with the observation $i j$. Mean separation was performed using the Tukey's multiple range test at $5 \%$ significance level.

\section{Results}

\section{Chemical composition of the tested feeds}

The chemical composition of the DDGS co-products and SBM is presented in Table 1. As proteinaceous feed, the tested DDGS contained less CP (33-39\%), more EE (1.7-3.9 \%), more fiber (52-58 \% NDF and 30-35 \% ADF), and less crude ash (1.4-6.5\%) compared to the values in SBM.

\section{Ruminal degradation kinetics of DM and CP}

The mean DM degradation variables across the feeds are presented in Table 2. The mean for the filterable and soluble DM A fraction ranged from 13.6 to $37.2 \%$ and was the highest with wheat DDGS, intermediate with corn DDGS and SBM, and the lowest with HP-DDGS $(P<0.001)$, whereas the mean of the degradable B fraction of DM ranged from 49.5 to $69.0 \%$ and was the lowest with corn and wheat DDGS, intermediate with HPDDGS and the highest with SBM $(P<0.001)$. The mean values of the $C$ fraction, or ruminally undegradable $D M$, was highest for HP-DDGS, followed by corn DDGS, and then wheat DDGS and SBM $(P<0.001)$.

Mean values of ruminal $C P$ degradation variables are presented in Table 2 . The mean for filterable and soluble A fraction of CP was greatest for wheat DDGS (26.5\%), intermediate on corn DDGS (19.7\%), and lowest for HP-DDGS and SBM (average $9.0 \%)(P<0.001)$. The highest and lowest degradable $\mathrm{B}$ fraction of $\mathrm{CP}$ was recorded for SBM $(87.2 \%)$ and HP-DDGS (49.8 \%), respectively. The range of the $\mathrm{C}$ fraction for $\mathrm{CP}$ was from $4.7 \%$ for wheat DDGS to $41.2 \%$ for HP-DDGS.

Mean percentages for the degradation rate of the degradable B fraction for DM and CP, within $48 \mathrm{~h}$ of incubation, differed considerably among the 4 feeds, ranging from 5.0 to $13.3 \% \mathrm{~h}^{-1}(\mathrm{SE}=0.97 ; P<0.001)$ and 3.9 to $17.6 \% \mathrm{~h}^{-1}(\mathrm{SE}=0.64 ; P<0.001)$, respectively, with the lowest rate for corn and HP-DDGS being recorded and the highest rate for SBM (Table 2).

The ED of DM was higher for wheat DDGS and SBM than for corn DDG and HP-DDGS (Table 3). The ED of $\mathrm{CP}$, assuming a passage rate of $0.06 \mathrm{~h}^{-1}$, showed that HP-DDGS was the lowest DIP source, followed by corn DDGS (42.5\%), and then SBM and wheat DDGS (72.6 \%) (Table 3).

As a function of residence time in the rumen, the amount of DM and CP disappearance for the test feeds is presented in Fig. 1. Among the feeds, wheat DDGS and SBM proteins were rapidly disappeared; approximately 84 and $74 \%$ of their CP fraction was disappeared during the first $12 \mathrm{~h}$ of incubation, respectively, thereby showing a steep increase in disappearance during the

Table 1 Chemical composition of soybean meal and dried distillers grains co-products ${ }^{\mathrm{a}, \mathrm{b}}$

\begin{tabular}{|c|c|c|c|c|c|}
\hline Item (DM basis) & Soybean meal & Wheat DDGS & Corn DDGS & HP-DDGS & SE \\
\hline Dry matter, \% & 92.4 & 86.5 & 86.5 & 90.0 & 0.05 \\
\hline Organic matter & 92.8 & 93.5 & 95.5 & 98.6 & 0.26 \\
\hline Crude protein (CP) & 52.2 & 38.1 & 33.3 & 38.8 & 0.38 \\
\hline True protein, $\%$ of CP & 89.9 & 84.6 & 91.9 & 93.0 & 1.33 \\
\hline Non-protein nitrogen, $\%$ of CP & 10.1 & 15.4 & 8.10 & 7.00 & 1.33 \\
\hline Ether extract & 0.77 & 2.63 & 3.92 & 1.66 & 0.20 \\
\hline Neutral detergent fiber (NDF) & 34.5 & 56.6 & 52.3 & 58.4 & 2.32 \\
\hline Acid detergent fiber & 12.9 & 29.7 & 31.9 & 35.3 & 0.25 \\
\hline Crude ash & 7.22 & 6.54 & 4.52 & 1.41 & 0.26 \\
\hline
\end{tabular}

${ }^{a} D D G S$ distillers dried grains with solubles, HP-DDGS high-protein corn DDGS

${ }^{\mathrm{b}}$ Means of 3 observations 
Table 2 Dry matter (DM) and crude protein (CP) degradation characteristics of soybean meal and dried distillers grains co-products ${ }^{1,2}$

\begin{tabular}{|c|c|c|c|c|c|c|}
\hline Item & Soybean meal & Wheat DDGS & Corn DDGS & HP-DDGS & SE & $P$ value \\
\hline $\mathrm{DM}(\%)$ & 92.4 & 86.5 & 86.5 & 90.0 & 0.1 & - \\
\hline \multicolumn{7}{|l|}{ DM fractions (\% of DM) } \\
\hline $53-\mu \mathrm{m}$ filterable and soluble A fraction & $28.4^{b}$ & $37.2^{\mathrm{a}}$ & $28.9^{b}$ & $13.6^{c}$ & 0.6 & $<0.001$ \\
\hline Degradable B fraction & $69.0^{\mathrm{a}}$ & $49.5^{c}$ & $51.0^{c}$ & $55.3^{b}$ & 1.4 & $<0.001$ \\
\hline Undegradable C fraction & $2.6^{\mathrm{d}}$ & $13.3^{\mathrm{c}}$ & $20.1^{b}$ & $30.9^{a}$ & 1.2 & $<0.001$ \\
\hline$K_{d} B^{3}\left(\% h^{-1}\right)$ & $13.3^{\mathrm{a}}$ & $9.1^{\mathrm{b}}$ & $5.3^{c}$ & $5.0^{c}$ & 1.0 & $<0.001$ \\
\hline CP (\%) & 52.2 & 38.1 & 33.3 & 38.8 & 0.4 & - \\
\hline \multicolumn{7}{|l|}{$\mathrm{CP}$ fractions (\% of CP) } \\
\hline 53- $\mu \mathrm{m}$ filterable and soluble A fraction & $8.9^{c}$ & $26.5^{\mathrm{a}}$ & $19.7^{\mathrm{b}}$ & $9.0^{c}$ & 1.9 & $<0.001$ \\
\hline Degradable B fraction & $87.2^{\mathrm{a}}$ & $67.8^{b}$ & $50.6^{b c}$ & $49.8^{c}$ & 4.0 & 0.001 \\
\hline Undegradable C fraction & $3.9^{c}$ & $4.7^{c}$ & $29.7^{b}$ & $41.2^{\mathrm{a}}$ & 3.3 & $<0.001$ \\
\hline$K_{d} B^{4}\left(\% h^{-1}\right)$ & $17.6^{\mathrm{a}}$ & $11.6^{\mathrm{b}}$ & $4.9^{c}$ & $3.9^{c}$ & 0.6 & $<0.001$ \\
\hline
\end{tabular}

${ }^{1} D D G S$ distillers dried grains with solubles, HP-DDGS high-protein corn DDGS

${ }^{2}$ Means of 12 observations

${ }^{3} K_{d} B=$ degradation rate of degradable $B$ fraction

${ }^{a-d}$ Means with different superscripts within the same row differ $(P<0.05)$

first hours of incubation. Both DM and CP disappearance after $48 \mathrm{~h}$ of incubation followed the same trend, with lower $(P<0.001)$ and higher rates of disappearance resulting from HP-DDGS and SBM, or wheat DDGS, respectively.

\section{Discussion}

\section{Chemical composition}

The large difference in $\mathrm{CP}$ content across the 4 feeds was comparable to those mentioned in published reports [18-20]. The greater CP content found in wheat DDGS as compared to corn DDGS in the present study was in agreement with two previous reports $[8,21]$, which attributed the difference to a higher $\mathrm{CP}$ content in wheat. In general, the results of this experiment in chemical composition of the feeds were comparable to the mean reported values of the three studies with corn and wheat DDGS $[8,22,23]$. These studies reported that wheatbased DDGS is characterized by a higher concentration of CP, 42.7 vs. $31.4 \%$, and similar NDF, 34.7 and $37.5 \%$, respectively.

Among the different types of DDGS co-products, HPDDGS is generally recognized for its reduced concentration of EE, ADF, and NDF, because during its production process much of the fiber is removed in de-hulling [24]. However, in this experiment HP-DDGS had a proportionately higher concentration of dietary fiber and EE as compared to corn or wheat DDGS (Table 1). The difference in $\mathrm{CP}, \mathrm{EE}$, and fiber concentrations among the DDGS co-products is largely influenced by their concentrations in the original grain and the efficiency of starchto-ethanol fermentation $[17,21]$.

\section{In situ degradation kinetics}

Consistent with the results of this experiment, $\mathrm{Li}$ et al. [21] compared the CP degradation kinetics of wheat and corn DDGS, and reported that the A and B fractions were approximately 3.8 and $23.3 \%$ higher for wheat than

Table 3 In situ effective degradability of dry matter (DM) and crude protein (CP) at two passage rates ${ }^{1,2}$

\begin{tabular}{|c|c|c|c|c|c|c|}
\hline Item & Soybean meal & Wheat DDGS & Corn DDGS & HP-DDGS & SE & $P$ value \\
\hline \multicolumn{7}{|c|}{ Effective degradability of DM } \\
\hline$K_{p} B=0.025, h^{-1}$ & $86.5^{\mathrm{a}}$ & $76.0^{b}$ & $63.5^{\mathrm{c}}$ & $50.5^{d}$ & 0.5 & $<0.001$ \\
\hline$K_{p} B=0.06, h^{-1}$ & $75.9^{\mathrm{a}}$ & $67.0^{\mathrm{b}}$ & $52.8^{c}$ & $38.7^{d}$ & 0.9 & $<0.001$ \\
\hline \multicolumn{7}{|c|}{ Effective degradability of $\mathrm{CP}$} \\
\hline$K_{p} B=0.025, h^{-1}$ & $85.3^{\mathrm{a}}$ & $82.3^{\mathrm{a}}$ & $53.2^{\mathrm{b}}$ & $39.3^{c}$ & 1.4 & $<0.001$ \\
\hline$K_{\mathrm{p}} \mathrm{B}=0.06, \mathrm{~h}^{-1}$ & $73.9^{\mathrm{a}}$ & $71.2^{\mathrm{a}}$ & $42.5^{b}$ & $28.6^{c}$ & 1.5 & $<0.001$ \\
\hline
\end{tabular}

${ }^{1} D D G S$ distillers dried grains with solubles, HP-DDGS high-protein corn DDGS

${ }^{2}$ Means of 12 observations

Effective degradability $=\mathrm{A}+\mathrm{B}\left[K_{\mathrm{d}} \mathrm{B} /\left(K_{\mathrm{d}} \mathrm{B}+K_{\mathrm{p}} \mathrm{B}\right)\right]$, where $\mathrm{A}=53-\mu \mathrm{m}$ filterable and soluble fraction, $\mathrm{B}=$ degradable fraction, $\mathrm{C}=$ undegradable fraction, $K_{\mathrm{d}} \mathrm{B}=$ degradation rate of degradable $\mathrm{B}$ fraction, and $K_{\mathrm{p}} \mathrm{B}=$ ruminal passage rate of degradable $\mathrm{B}$ fraction

${ }^{a-d}$ Means with different superscripts within the same row differ $(P<0.05)$ 

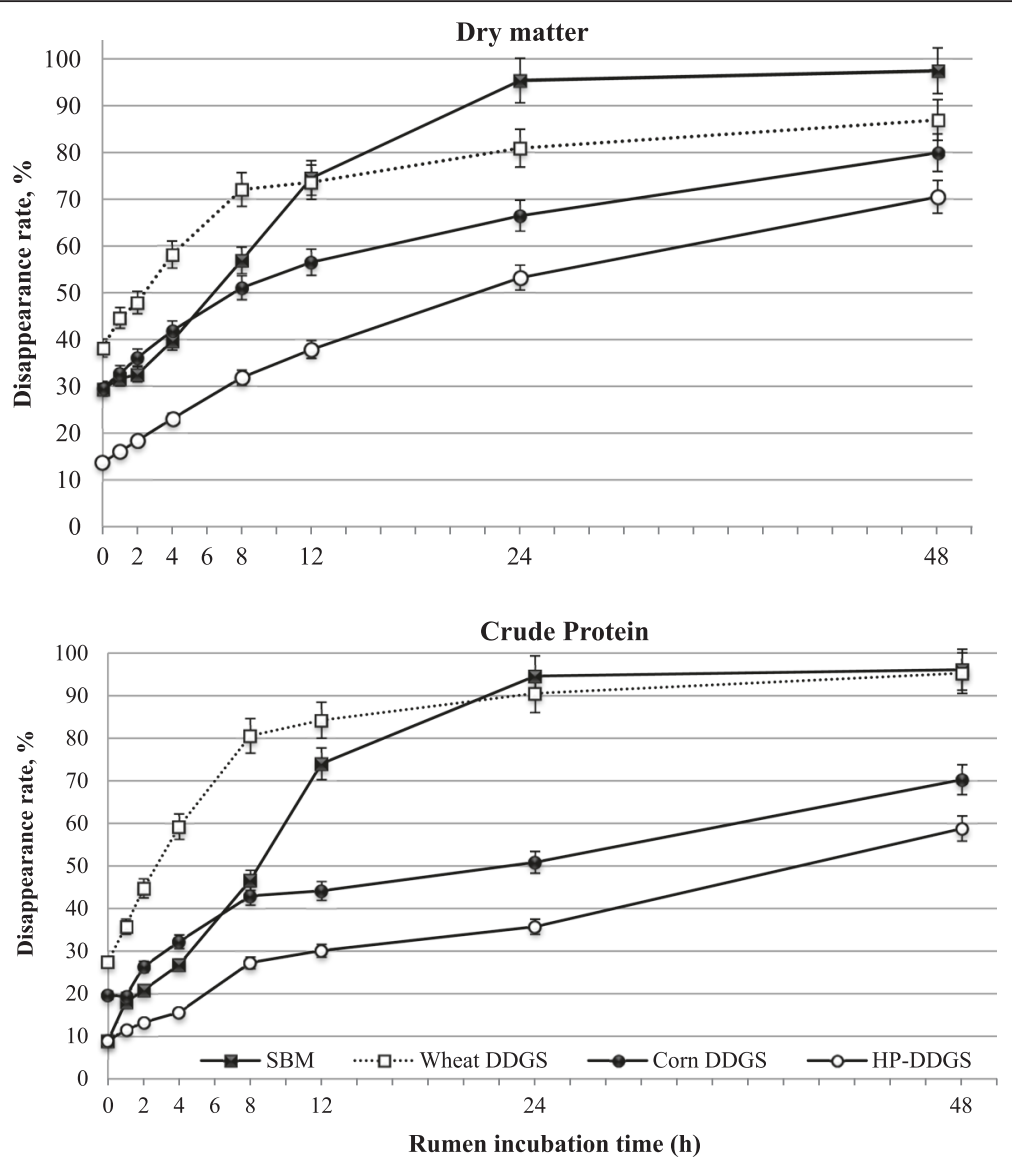

Fig. 1 In situ dry matter and crude protein disappearance rate of the tested feeds according to rumen incubation time. Error bars indicate SE

for corn DDGS, but the $K_{\mathrm{d}}$ of the B fraction was much lower for wheat DDGS $\left(2.7 \% \mathrm{~h}^{-1}\right)$ than for corn DDGS $\left(7.2 \% \mathrm{~h}^{-1}\right)$. The range of fraction $\mathrm{A}$ in the DDGS coproducts [corn, wheat, and HP-DDGS, from 9.0 to $26.5 \%$, respectively] is in contrast to the values reported by Kleinschmit et al. [25] for various sources of DDGS (15.9 to $19.7 \%$ ), and the values reported by Mjoun et al. [17] for corn DDGS, reduced-fat corn DDGS, and HPDDGS (ranging from 11.1 to $18.4 \%$ ).

The combination of fractions A and B was 96.1, 70.3, and $94.3 \%$ for SBM, HP-DDGS, and wheat DDGS, respectively, which is consistent with values reported for the same feeds in a recent experiment by Maxin et al. [18], but not for HP-DDGS, which was estimated to be $87.0 \%$. Mjoun et al. [17], studying the in situ CP degradability of SBM and DDGS, reported that the B fraction for CP was greatest with SBM and HP-DDGS (average $88.0 \%)$, followed by corn DDGS (76.8\%). These values are comparable to the results of this study for SBM; however, they are considerably higher for the DDGS coproducts. The degradation rate of the $\mathrm{B}$ fraction for $\mathrm{CP}$ was reported as $11.8 \% \mathrm{~h}^{-1}$ for SBM, which is lower than that recorded in this experiment $\left(17.6 \% \mathrm{~h}^{-1}\right)$.
Cao et al. [26] found that there is a linear relationship in the soluble A fraction between CP and the amount of solubles added to DDG during the production process, which may explain the variation in the A fraction among the DDGS co-products found in this experiment with those reported in the literature. The data for the undegradable $\mathrm{C}$ fraction on $\mathrm{CP}$ is in contrast with the study by Kleinschmit et al. [25], which reported that the $\mathrm{C}$ fraction varied from $2.1 \%$ for high-quality DDGS to 18.7 \% for a heat-damaged DDGS.

Consistent with this study's results, the two previous studies by Nuez-Ortín and Yu [8] and Chrenková et al. [27] reported that wheat DDGS had higher in situ CP degradability than corn DDGS. The greater protein degradability of SBM in the rumen, compared to the DDGS products, has already been extensively studied. Aines et al. [28] summarized several experiments and reported that the DDGS protein was 1.8fold less degradable compared with SBM protein. In an in situ trial by Salem et al. [29], 95.6 and $95.3 \%$ of SBM DM and CP degraded at a rate of 14.7 and $16.7 \% \mathrm{~h}^{-1}$, respectively, similar to the values we recorded in this study. 


\section{Effective degradability}

The higher ED of DM for wheat DDGS and SBM than for corn DDG and HP-DDGS might be partially explained by its high soluble fraction [ $28.4 \%$ and $37.2 \%$ of DM for wheat DDGS and SBM vs. 28.9 and $13.6 \%$ of DM for corn DDGS and HP-DDGS, respectively], and the higher degradable $\mathrm{B}$ fraction of DDGS co-products [49.5\% and $69.0 \%$ of DM for wheat DDGS and SBM vs. $51.0 \%$ and $55.3 \%$ of DM for corn DDGS and HPDDGS, respectively].

The estimated UIP, assuming the passage rate of $0.06 \mathrm{~h}^{-1}$, ranged from $26.1 \%$ for SMB to $71.4 \%$ for HPDDGS, which indicates that HP-DDGS is a good source of UIP for ruminants. This compares with previous studies reporting that UIP constituted approximately $55.2 \%$ of CP in HP-DDGS [30] and $55 \%$ of CP in corn DDGS [31]. The average amount of UIP (\% of CP) for corn DDGS, assuming $K_{\mathrm{p}} \mathrm{B}=0.06, \mathrm{~h}^{-1}$, was estimated to be $57.5 \%$, which is comparable to the value (54.9\%) reported in the National Research Council's (NRC) Nutrient Requirements of Beef Cattle [32].

The amount of UIP in this study (assumed $K_{\mathrm{p}} \mathrm{B}=$ $\left.0.06 \mathrm{~h}^{-1}\right)$ differed from the results reported by Mjoun et al. [17] $\left(K_{\mathrm{p}} \mathrm{B}=0.06 \mathrm{~h}^{-1}\right)$ : 26.1 vs. $32.3 \%$ of CP for SBM, 57.5 vs. $52.3 \%$ of $\mathrm{CP}$ for corn DDGS, and 71.4 vs. $54.5 \%$ of CP for HP-DDGS, in the present study vs. Mjoun et al. [17], respectively. The amount of UIP reported by Li et al. [21] assuming $K_{\mathrm{p}} \mathrm{B}=0.06 \mathrm{~h}^{-1}$, is considerably higher for wheat DDGS as compared to this experiment (a 22-percentage-unit difference), however the value reported for corn DDGS was comparable to the current observation.

Consistent with previous reports, this study reaffirmed that DDGS co-products have a high concentration of ruminally undegraded intake protein (by-pass protein), which could be due to much of their protein being heatdenatured yeast that was heated during the distillation and concentration process [33]. This results in the proteins being resistant to lyses and ruminal microbial degradation [3].

Endosperm is mainly composed of zein protein, which is known to be resistant to ruminal degradation [34, 35]. During the production process of HP-DDGS, a large proportion of proteins originate from endosperm, which might explain why HP-DDGS had the highest proportion of UIP compared to other DDGS co-products.

To meet the requirements for metabolizable protein, and minimize $\mathrm{N}$ excretion, the dietary protein must be divided into DIP and UIP fractions, which requires a precise estimation of protein degradation in the rumen for the feed ingredients included in the diet [10]. Therefore, the estimates of UIP reported in this experiment might be particularly useful for farmers and feed manufactures to more precisely formulate the diet.
The variations observed in the results of this study compared with those reported in the literature might be explained in part by differences in feed particle size or laboratory-to-laboratory variations in analytical procedures $[3,36]$. Moreover, processing methods, such as the temperature and drying time of DDGS may vary widely between ethanol producing plants. These are known to be the factors contributing to increased neutral detergent-insoluble $\mathrm{CP}$ and acid detergent-insoluble $\mathrm{CP}$, and therefore contributes to the variability in solubility of $\mathrm{CP}$ in the rumen [21,37]. However, information on the details of the feeds used, and the processing technologies applied in the plants, was not available for the DDGS co-products.

\section{Conclusions}

The ruminal CP degradation of the DDGS co-products varied considerably in the present study, which could have been caused by variations in both the quality of the DDGS co-products and the production technology of the individual processing plants. This study showed that the observed UIP content (\% of CP) was as follows: HPDDGS $(71.4 \%)>$ corn DDGS $(57.5 \%)>$ wheat DDGS $(28.8 \%)>$ soybean meal $(26.1 \%)$, showing that HPDDGS and corn DDGS are a good source of UIP. This information can be used as basic data for a more accurate formulation of rations for beef and dairy cattle.

\section{Abbreviations}

ADF, acid-detergent fiber; CP, crude protein; DDGS, dried distillers grains plus solubles; DIP, degraded intake protein; DM, dry matter; ED, effective ruminal degradability; EE, ether extract; HP-DDGS, high-protein distillers grains plus solubles; NDF, neutral-detergent fiber; NPN, non-protein nitrogen; SBM, soybean meal; UIP, undegraded intake protein

\section{Acknowledgements}

This study was carried out with the support of the "Cooperative Research Program for Agriculture Science and Technology Development (Project No. PJ009382012015)", the Rural Development Administration, Republic of Korea. Special thanks go to Dr. J. S. Shin and his graduate students, Mr. Y. J. Kim, and Mr. C. S. Choi in Kang-Won University for their support of the cannulated Hanwoo cows.

\section{Funding}

This study was carried out with the support of the "Cooperative Research Program for Agriculture Science and Technology Development (Project No. PJ009382012015)", the Rural Development Administration, Republic of Korea.

\section{Availability of data and materials} Not applicable.

\section{Authors' contributions}

$\mathrm{YH}$ carried out the in situ bag experiment using cannulated cattle. F made substantial contributions in writing the manuscript and literature review. DY performed the statistical analysis. WS made major contributions to the study conception, design, and management as the corresponding author. All authors read and approved the final manuscript.

\section{Competing interests}

The authors declare that they have no competing interests. 


\section{Consent for publication}

All the authors have agreed that it should be submitted to Journal of Animal Science and Technology. No part of this work has been published elsewhere or under consideration in another journal. The manuscript has not previously submitted to Journal of Animal Science and Technology.

\section{Ethics approval and consent to participate}

All procedures involving animals were reviewed and approved by the Konkuk University Institutional Animal Care and Use Committee.

Received: 19 March 2016 Accepted: 29 July 2016

\section{Published online: 01 September 2016}

\section{References}

1. Boila $R$, Ingalls J. The ruminal degradation of dry matter, nitrogen and amino acids in wheat-based distillers' dried grains in sacco. Anim Feed Sci Technol. 1994:48:57-72.

2. Castro-Pérez Bl, Estrada-Angulo A, Ríos FG, Dávila-Ramos H, Robles-Estrada JC, Contreras-Pérez G, Calderón-Cortés JF, López-Soto MA, Barreras A, Plascencia A. Effects of replacing partially dry-rolled corn and soybean meal with different levels of dried distillers grains with solubles on growth performance, dietary energetics, and carcass characteristics in hairy lambs fed a finishing diet. Small Rumin Res. 2014;119:8-15.

3. Klopfenstein TJ, Erickson GE, Bremer VR. Use of distillers by-products in the beef cattle feeding industry. J Anim Sci. 2008;86:1223-31.

4. National Research Council (NRC). Nutrient requirements of small ruminants. Sheep, goats, cervids and New World camelids. Washington, DC: Natl. Acad. Press; 2007

5. Paz H, Castillo-Lopez E, Ramirez-Ramirez H, Christensen D, Klopfenstein T, Kononoff P. Invited review: ethanol co-products for dairy cows: there goes our starch... now what? Can J Anim Sci. 2013;93:407-25.

6. Westreicher-Kristen E, Steingass H, Rodehutscord M. In situ ruminal degradation of amino acids and in vitro protein digestibility of undegraded CP of dried distillers' grains with solubles from European ethanol plants. Animal. 2013;7:1901-9.

7. Russell JB, O'Connor JD, Fox DG, Van Soest PJ, Sniffen CJ. A net carbohydrate and protein system for evaluating cattle diets: I. Ruminal fermentation. J Anim Sci. 1992;70:3551-61.

8. Nuez-Ortín WG, Yu P. Nutrient variation and availability of wheat DDGS, corn DDGS and blend DDGS from bioethanol plants. J Sci Food Agric. 2009; 89:1754-61.

9. Spiehs MJ, Whitney MH, Shurson GC. Nutrient database for distiller's dried grains with solubles produced from new ethanol plants in Minnesota and South Dakota. J Anim Sci. 2002:80:2639-45.

10. Hedqvist $H$, Udén P. Measurement of soluble protein degradation in the rumen. Anim Feed Sci Technol. 2006;126:1-21.

11. US Grains Council. A guide to distillers' dried grains with solubles (DDGS). 3rd ed. 2012. http://www.ethanolrfa.org/wp-content/uploads/2015/11/2012 DDGS_Handbook-1.pdf. Accessed 3 Jan 2016.

12. AOAC. Official methods of analysis. 15th ed. Washington, DC: Association of Official Analytical Chemists; 1990.

13. Van Soest PJ, Robertson J, Lewis B. Methods for dietary fiber, neutral detergent fiber, and nonstarch polysaccharides in relation to animal nutrition. J Dairy Sci. 1991;74:3583-97.

14. Licitra G, Hernandez T, Van Soest P. Standardization of procedures for nitrogen fractionation of ruminant feeds. Anim Feed Sci Technol. 1996;57:347-58.

15. Kim Y, Cho W, Hong S, Oh Y, Kwak W. Yield, nutrient characteristics, ruminal solubility and degradability of spent mushroom (Agaricus bisporus) substrates for ruminants. Asian Australas J Anim Sci. 2011:24:1560-8.

16. Ørskov E, McDonald I. The estimation of protein degradability in the rumen from incubation measurements weighted according to rate of passage. J Agric Sci. 1979;92:499-503

17. Mjoun K, Kalscheur K, Hippen A, Schingoethe D. Ruminal degradability and intestinal digestibility of protein and amino acids in soybean and corn distillers grains products. J Dairy Sci. 2010;93:4144-54.

18. Maxin G, Ouellet D, Lapierre H. Ruminal degradability of dry matter, crude protein, and amino acids in soybean meal, canola meal, corn, and wheat dried distillers grains. J Dairy Sci. 2013;96:5151-60.

19. Robinson P, Karges K, Gibson M. Nutritional evaluation of four co-product feedstuffs from the motor fuel ethanol distillation industry in the Midwestern USA. Anim Feed Sci Technol. 2008;146:345-52.
20. Walter L, Aalhus J, Robertson WM, McAllister TA, Gibb D, Dugan ME, Aldai N McKinnon J. Evaluation of wheat or corn dried distillers' grains with solubles on performance and carcass characteristics of feedlot steers. Can J Anim Sci. 2010;90:259-69.

21. Li C, Li J, Yang W, Beauchemin K. Ruminal and intestinal amino acid digestion of distiller's grain vary with grain source and milling process. Anim Feed Sci Technol. 2012;175:121-30.

22. Widyaratne G, Zijlstra R. Nutritional value of wheat and corn distiller's dried grain with solubles: digestibility and digestible contents of energy, amino acids and phosphorus, nutrient excretion and growth performance of grower-finisher pigs. Can J Anim Sci. 2007;87:103-14.

23. Abdelqader M, Oba M. Lactation performance of dairy cows fed increasing concentrations of wheat dried distillers grains with solubles. J Dairy Sci. 2012;95:3894-904.

24. Widmer M, McGinnis L, Stein H. Energy, phosphorus, and amino acid digestibility of high-protein distillers dried grains and corn germ fed to growing pigs. J Anim Sci. 2007;85:2994-3003.

25. Kleinschmit DH, Anderson $J$ L, Schingoethe DJ, Kalscheur KF, Hippen AR. Ruminal and intestinal degradability of distillers grains plus solubles varies by source. J Dairy Sci. 2007;90:2909-18.

26. Cao Z, Anderson J, Kalscheur K. Ruminal degradation and intestinal digestibility of dried or wet distillers grains with increasing concentrations of condensed distillers solubles. J Anim Sci. 2009;87:3013-9.

27. Chrenková M, Ceresnaková Z, Formelová Z, Poláciková M, Mlyneková Z, Fl'ak $P$. Chemical and nutritional characteristics of different types of DDGS for ruminants. J Anim Feed Sci. 2012;21:425-35.

28. Aines GE, Klopfenstein TJ, Stock RA. Distillers grains: Agricultural Research Division, University of Nebraska-Lincoln. 1987.

29. Salem AZM, Szumacher-Strabel M, López S, Khalil MS, Mendoza GD, Ammar $\mathrm{H}$. In situ degradability of soyabean meal treated with Acacia saligna and Atriplex halimus extracts in sheep. J Anim Feed Sci. 2012;21:447-57.

30. Kelzer JM, Kononoff PJ, Tedeschi LO, Jenkins TC, Karges K, Gibson ML. Evaluation of protein fractionation and ruminal and intestinal digestibility of corn milling co-products. J Dairy Sci. 2010;93:2803-2815.

31. Schingoethe DJ. Corn coproducts for cattle. In: Proc. 40th Eastern Nutr. Conf. Ottawa: Animal Nutrition Association of Canada; 2004. p. 39-47.

32. NRC. Nutrient Requirements of Beef Cattle (Updated 7th Ed.). Washington, DC: Natl. Acad. Press; 2000

33. Bruning $\mathrm{CL}$, Yokoyama MT. Characteristics of live and killed brewer's yeast slurries and intoxication by intraruminal administration to cattle. J Anim Sci. 1988;66:585-91.

34. Little CO, Mitchell Jr GE, Potter GD. Nitrogen in the abomasum of wethers fed different protein sources. J Anim Sci. 1968;27:1722-6.

35. McDonald I. The extent of conversion of food protein to microbial protein in the rumen of the sheep. Biochem J. 1954;56:120-5.

36. Batajoo KK, Shaver RD. In situ dry matter, crude protein, and starch degradabilities of selected grains and by-product feeds. Anim Feed Sci Technol. 1998:71:165-76.

37. Nuez-Ortín WG, Yu P. Estimation of ruminal and intestinal digestion profiles, hourly effective degradation ratio and potential $\mathrm{N}$ to energy synchronization of co-products from bioethanol processing. J Sci Food Agric. 2010;90:2058-67.

\section{Submit your next manuscript to BioMed Central and we will help you at every step:}

- We accept pre-submission inquiries

- Our selector tool helps you to find the most relevant journal

- We provide round the clock customer support

- Convenient online submission

- Thorough peer review

- Inclusion in PubMed and all major indexing services

- Maximum visibility for your research

Submit your manuscript at www.biomedcentral.com/submit 